\title{
Change of Peptides and Free -Amino Acids Contents during Nanjing Dry-Cured Duck Processing
}

\author{
Shuai Shi ${ }^{1}$, Ying-lin $\mathrm{Lu}^{2}$, Xing-lian $\mathrm{Xu}^{3} *$ \\ 1,2 Jiangsu Agri-Animal Husbandry Vocational College, China \\ ${ }^{2}$ Key Laboratory of Agricultural and Animal Products Processing and Quality Control, Nanjing Agricultural University, \\ Nanjing, 210095, China
}

\begin{abstract}
In order to explore the relationship between the change of peptides and free-amino acid (FAA) and its unique flavour, Dry-cured duck samples of different processing phases were used to study the change of free-amino acid by High Performance Liquid Chromatography (HPLC) in this paper, meanwhile the trichloroacetic acid precipitation method for modeling use to establish the quantitative predicated peptides. The changes of small peptides and free amino acids in the process were studied. The results showed that the level and amount of proteolysis increased with the processing time at traditional technology, meanwhile the amount of peptides were positively correlated with $F A A$ contents $\left(R^{2}=0.86\right)$.
\end{abstract}

Keywords - dry-cured duck, Free-amino acids, proteolysis, Peptides.

\section{INTRODUCTION}

Special flavor of cured meat product depended on special processing technology of different countries and regions, Monica Flores ${ }^{[1]}$ and other scientists studied the flavor and sensory descriptions of correlation of Serrano ham of amino acids, peptides etc by HPLC and capillary electrophoresis and sensory analysis method. the flavor material with proportional

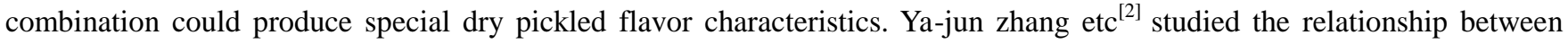
protein degradation products and ham quality in jinhua ham. The analysis showed that the essential amino acid composition of proteins in jinhua ham made were more consistent with recommendation model and produced a large number of low molecular weight proteins and peptides after processing. The Nanjing dry-cured duck was a kind of traditional Chinese meat product, which was popular with consumers. However, the study on the mechanism of protein degradation in the processing of protein has not been reported.

Based on the different stages of processing in Nanjing dry-cured duck as the research object, the change of small peptides and free amino acid were determined during product process by HPLC, which provided theoretical basis for the modern control technology for Nanjing dry-cured duck.

\section{MATERIAL AND METHOD}

\subsection{Experimental Materials}

The thigh muscle sample during seven control critical points of manufacturing process (raw material, dry salting, wet salted, fold, dried $5 \mathrm{~d}, 10 \mathrm{~d}$ dry, dry $15 \mathrm{~d}$ ) were removed as test materials, three animals were selected from every process control point respectively, transferred to lab and stored at $-80^{\circ} \mathrm{C}$ for analysis. Samples provided by the Nanjing Rurun Group Jin Furun Food Co., LTD.

\subsection{Reagents and Instruments}

\subsubsection{Reagents}

acetonitrile, trifluoroacetic acid, pure chromatographic; 2 mercaptoethanol, sodium dodecyl sulfate, Tris, disodium hydrogen phosphate, sodium dihydrogen phosphate etc, analytical pure;acrylamide (Shanghai colorful), methylene double acrylamide (Promega), TEMED (Promega), ammonium persulfate (Shanghai colorful), the molecular weight protein Marker (Promega).

\subsubsection{Experimental Instruments}

High speed dispersion (ultra-turrax T25), high-speed centrifuge (Beckman allegra 64R), 10kDa ultrafiltration membrane, high performance liquid chromatograph (Agilent1100), electrophoresis (602S stabilized current meter)

\subsection{Test Methods}

\subsubsection{Study on small peptide of protein in duck :}

$3 \mathrm{~g}$ duck thigh muscles were accurately weighed, added $60 \mathrm{ml} 0.2 \mathrm{~mol} / \mathrm{L}$ phosphate buffer solution (pH6.5), homogenized with high-speed disperser $(6000 \mathrm{rpm}) 3 \mathrm{~min}$, then high-speed centrifugation $\left(10,000 \times \mathrm{g}, 4^{\circ} \mathrm{C}\right) 20 \mathrm{~min}$. the supernatant $1 \mathrm{ml}$ took out, 
added $2.5 \mathrm{ml}$ acetonitrile, centrifuge $\left(15,000 \times \mathrm{g}, 4^{\circ} \mathrm{C}, 20 \mathrm{~min}\right), 2.5 \mathrm{ml}$ supernatant took out, vacuum drying to remove water and organic solvents, with $40 \mu \mathrm{l}$ of eluent A ( $0.05 \%$ Fluoroacetic acid). $20 \mu \mathrm{l}$ of sample took into the $\mathrm{C} 18$ column (inner diameter $4.5 \mathrm{~mm}$, length $250 \mathrm{~mm})$ for HPLC determination. Eluent A $(0.05 \%$ trifluoroacetic acid), eluent B (acetonitrile: water: trifluoroacetic acid $=60: 40: 0.04)^{[3,4,5]}$.Elution process: first with eluent A plus $1 \%$ eluent B washed 5 min respectively, and then gradient elution, eluent B from $1 \%$ gradually was increased to $100 \%$, elution $25 \mathrm{~min}$, eluent speed control with $0.9 \mathrm{ml} / \mathrm{min}$, detection wavelength of $214 \mathrm{~nm}$.

\subsubsection{Determination of Free amino acid (FAA)}

With reference to Ventanas ${ }^{[4]}$ and Cordoba ${ }^{[6]}$ and other methods, some changes have been made. The specific method was as follows: after the natural thawing of the sample, the visible fat and fascia were removed, minced, about $5 \mathrm{~g}$ (accurate to $0.001 \mathrm{~g}$ ) weighed, deionized water 20ml added, in the ice bath with ULTRA TURRAX (IKAT18basic, German) (22,000 rpm, each $10 \mathrm{~s}$, interval $10 \mathrm{~s}$ ), then $10 \%$ of the sulfosalicylic acid $20 \mathrm{ml}$ mixed evenly, at $4^{\circ}$ tor $17 \mathrm{~h}$, the medium speed filter paper, the filtrate adjusted first with $4 \mathrm{~mol} / \mathrm{LKOH}$ to the $\mathrm{pH}$ Value 6.0 , and then with deionized water to $50 \mathrm{ml}, 10 \mathrm{kDa}$ ultrafiltration membrane ultrafiltration to remove macromolecules. The ultrafiltrate was derivatized with AccQ Fluor Reagent Kit (P/N WAT052880) and the free amino acid content in the sample was determined by HPLC.The main technical parameters of HPLC: AccQ.Tag column (Nava-PakC18, $3.9 \times 150 \mathrm{~mm}, \mathrm{~F} 0.4 \mu \mathrm{m}$ ), column temperature $37^{\circ} \mathrm{C}$; injection volume $10 \mu \mathrm{l}$; Waters515 double pump gradient elution, eluent A AccQ Tag Liquid A was diluted 11 times with ultrapure water. The eluent B was $60 \%$. The elution rate was $1.0 \mathrm{ml} \cdot \mathrm{min}^{-1}$, the elution time was $50 \mathrm{~min}$, and the Waters $2487 \mathrm{UV}$ detector was used.

\subsection{Statistical Analysis}

Using SASO.2 ANOVA analysis of variance, and with Duncan's multiple comparison, the difference was significant $(\mathrm{p} \leq 0.05)$.

\section{RESULTS AND DISCUSSION}

\subsection{Changes of Protein Peptides in Duck Muscle}

It can be seen from Figure 1, in the processing stage of the duck, from the raw material to dry $5 \mathrm{~d}$ retention time was short, the content of the polarity material in the dry picking stage first declined, and then increased and stabilized. In the dry stage of $10 \mathrm{~d}$, a new peptide peak appeared at 7.002, 12.632 and $17.429 \mathrm{~min}$, and the peptide peak were decreased at 6.330 and $9.664 \mathrm{~min}$. This may be related to the fact that "high levels of small peptides imparted flavor to the product and low levels of peptides made the product sweet" ${ }^{[7,8]}$.

The main peak area of various major peptides in thigh meat was shown in Table 1. RP-HPLC analysis of small peptides showed that a total of ix significant peptides elution peaks were obtained in the ducks and the peak area of each elution peak was calculated by integral method. The number of elution peaks were consistent with that of Eugenio Rodriguez-Nune ${ }^{[9]}$, and the first six peaks were concentrated in the first $14 \mathrm{~min}$, indicating that the polarity of the polypeptide in the duck was mostly strong. ( $\mathrm{P}<0.05)$, which was probably due to the fact that the peptides were dissolved in the pickled liquid during the pickling stage $(\mathrm{P}<0.05)$, and the total area of the peak increased significantly $(\mathrm{P}<0.05)$, followed by dehydration mature process, endogenous enzyme decomposition of the protein as a short peptide

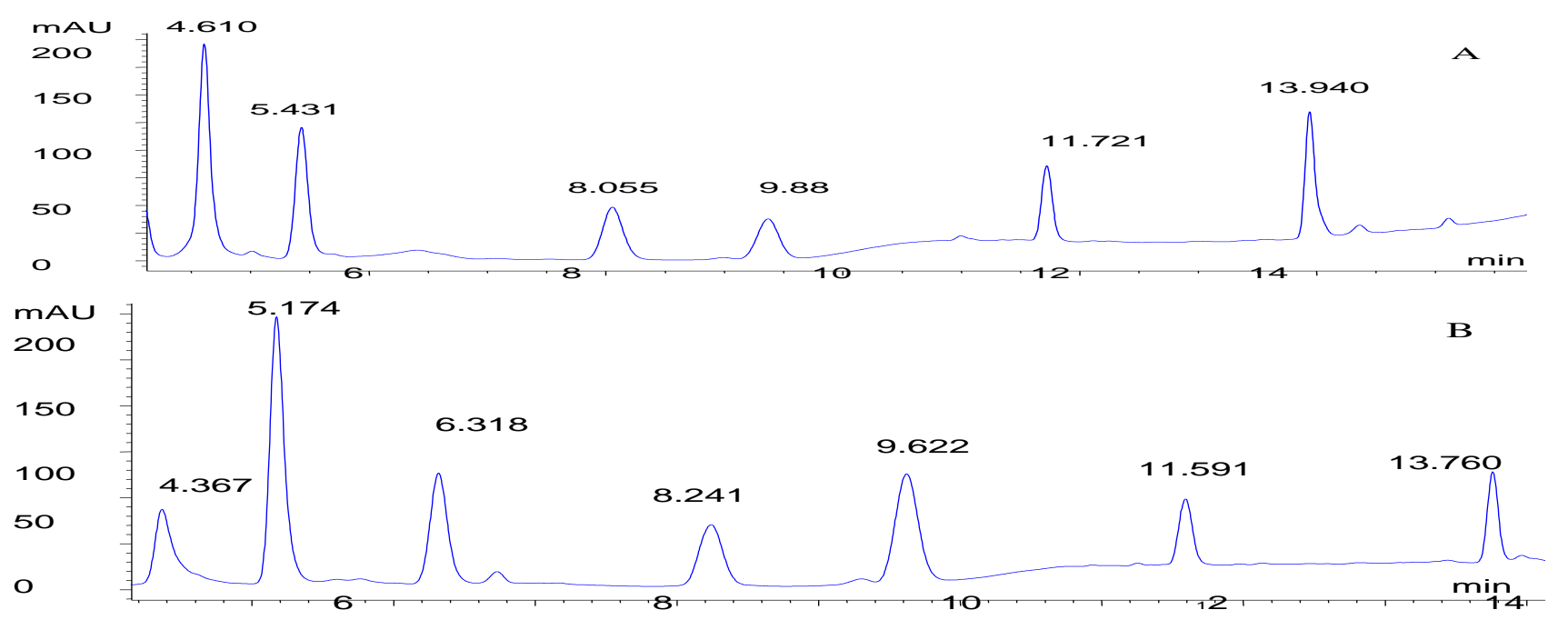



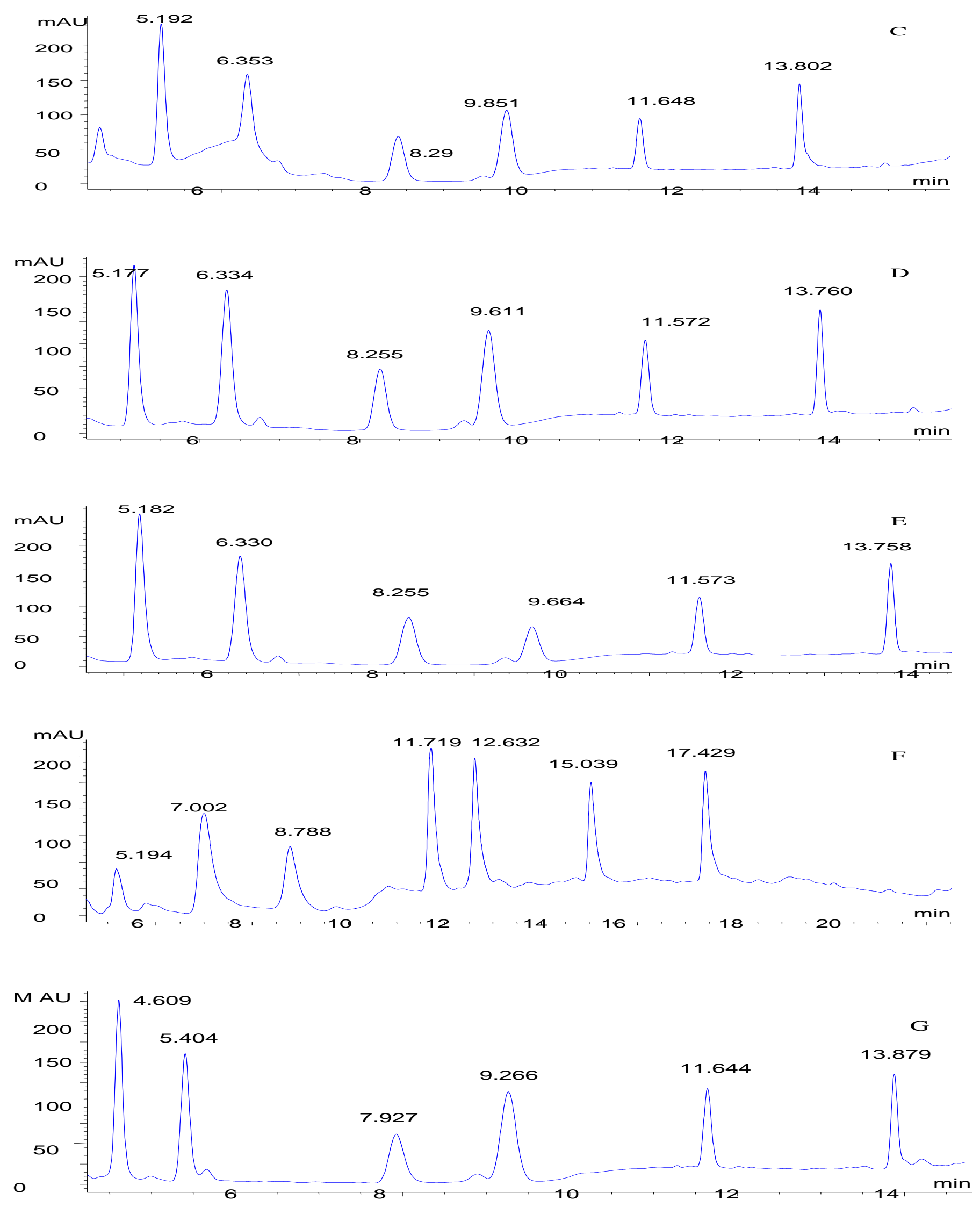

FIGURE 1: HPLC PATTERNS OF PEPTIDES IN LEG EXTRACT WITH DIFFERENT PROCESSING PERIOD

A-material ; B-cured ; C-salted ; D-overlaped ; E-drying 5d ; F-drying 10d ; G-drying 15d 
TABLE 1

THE RESULT OF PEPTIDES OF HPLC IN LEG DURING PROCESSING PERIOD OF DRY-CURED DUCK [UNITS: $\operatorname{AREA}\left(\mathrm{mAU}^{*} \mathbf{s}\right)$

\begin{tabular}{|c|c|c|c|c|c|c|c|}
\hline Retain time(min) & $\begin{array}{c}\text { raw } \\
\text { material }\end{array}$ & cured & salted & overlaped & drying 5d & $\begin{array}{c}\text { drying } \\
\text { 10d }\end{array}$ & drying 15d \\
\hline \multirow{2}{*}{4.90} & 1284.80 & $1828.93 \pm 370$ & $406.50 \pm 15$ & $1202.33 \pm 11$ & $1659.17 \pm 1$ & 453.30 & 1332.47 \\
& $\pm 187.71^{\mathrm{c}}$ & $.84^{\mathrm{a}}$ & $9.50^{\mathrm{d}}$ & $3.82^{\mathrm{c}}$ & $85.73^{\mathrm{ab}}$ & $\pm 23.21^{\mathrm{d}}$ & $\pm 145.04^{\mathrm{bc}}$ \\
\hline \multirow{2}{*}{6.02} & $825.40 \pm 68.4$ & $957.60 \pm 134$. & $1436.17 \pm 9$. & 117.77 & $1364.20 \pm 3$ & $1649.47 \pm$ & $1071.30 \pm 34$. \\
& $1^{\mathrm{e}}$ & $86^{\mathrm{de}}$ & $41^{\mathrm{ab}}$ & $306.39^{\mathrm{bcd}}$ & $39.16^{\mathrm{abc}}$ & $69.36^{\mathrm{a}}$ & $65^{\mathrm{cde}}$ \\
\hline \multirow{2}{*}{8.29} & $531.50 \pm 37.4$ & $694.131 \pm 41$. & 739.33 & 669.37 & 878.90 & 900.83 & $783.93 \pm$ \\
& $3^{\mathrm{c}}$ & $22^{\mathrm{b}}$ & $\pm 1.55^{\mathrm{b}}$ & $\pm 72.39^{\mathrm{b}}$ & $\pm 35.21^{\mathrm{a}}$ & $\pm 24.83^{\mathrm{a}}$ & $86.94^{\mathrm{a}}$ \\
\hline \multirow{2}{*}{9.88} & $435.40 \pm 27.1$ & $1152.13 \pm 295$ & $1099.53 \pm 2$ & 956.50 & 758.40 & $1217.70 \pm$ & $1268.57 \pm 20$ \\
& $5^{\mathrm{c}}$ & $.37^{\mathrm{a}}$ & $3.99^{\mathrm{ab}}$ & $\pm 354.55^{\mathrm{ab}}$ & $\pm 187.79^{\mathrm{bc}^{\mathrm{b}}}$ & $22.65^{\mathrm{a}}$ & $4.34^{\mathrm{a}}$ \\
\hline \multirow{2}{*}{11.77} & $403.77 \pm 67.0$ & $443.90 \pm 68.6$ & $477.70 \pm 10$. & 513.37 & 670.46 & $1056.73 \pm$ & $636.23 \pm$ \\
& $4^{\mathrm{d}}$ & $8^{\mathrm{cd}}$ & $16^{\mathrm{cd}}$ & $\pm 90.50^{\mathrm{c}}$ & $\pm 34.48^{\mathrm{b}}$ & $18.77^{\mathrm{b}}$ & $13.10^{\mathrm{a}}$ \\
\hline \multirow{2}{*}{13.99} & $676.13 \pm 33.0$ & $516.77 \pm$ & $813.30 \pm$ & 560.40 & 772.27 & $818.37 \pm$ & $742.13 \pm 128$. \\
& $2^{\mathrm{bc}}$ & $13.70^{\mathrm{d}}$ & $26.46^{\mathrm{a}}$ & $\pm 117.73^{\mathrm{cd}}$ & $\pm 31.58^{\mathrm{ab}}$ & $19.37^{\mathrm{a}}$ & $84^{\mathrm{ab}}$ \\
\hline \multirow{2}{*}{ total } & $4156.98 \pm 398$ & $5593.44 \pm 101$ & $4972.56 \pm 1$ & $5077.02 \pm 10$ & $6103.38 \pm$ & $6102.42 \pm$ & $5934.64 \pm \pm$ \\
& $.54^{\mathrm{b}}$ & $8.60^{\mathrm{a}}$ & $79.12^{\mathrm{ab}}$ & $54.88^{\mathrm{ab}}$ & $372.39^{\mathrm{a}}$ & $113.05^{\mathrm{a}}$ & $164.75^{\mathrm{a}}$ \\
\hline
\end{tabular}

Note: Area are expressed as mean \pm S.D. of triplicates; means within the same line with common superscripts are not significantly different $(P>0.05)$.

\subsection{Changes of Free Amino Acids in Duck Muscle}

The determination of the major free amino acids in thigh meat was shown in table 2. In the processing of duck, in addition to arginine, threonine, cysteine little change, the other kinds of free amino acid concentration with the processing have increased to varying degrees. Compared with the pre-pickled, most of the free amino acids in the duck were increased by 1-2 times, among which the glutamic acid increased most, more than 2 times, followed by aspartic acid, serine acid and isoleucine. At the end of the processing, the higher content of free amino acids was glutamic acid, arginine, histidine and threonine. From the point of view the changes in content, aspartic acid, proline, tyrosine, valine, lysine, isoleucine and leucine were consistent, at the beginning of pickled stage were little changed, and later each stage of continuous rise $(\mathrm{P}$ $<0.05$ ). From the total amount of change, the free amino acid from the beginning of the raw materials to dry $5 \mathrm{~d}$ continuous increase, and then a slight decline, which might be the amount of decomposition was greater than the amount produced by hydrolysis, decomposition into flavor small molecular components such as aldehydes, Alcohol compounds ${ }^{[10]}$.

TABLE 2

MAIN FAA CONTENT IN LEG DURING PROCESSING PERIOD OF DRY-CURED DUCK (unit : mg/100g)

\begin{tabular}{|c|c|c|c|c|c|c|}
\hline Items & material & cured & salted & drying 5d & drying 10d & drying 15d \\
\hline Asp & $12.25 \pm 0.81 \mathrm{bc}$ & $12.07 \pm 1.31 \mathrm{bc}$ & $10.16 \pm 2.96 \mathrm{c}$ & $16.37 \pm 1.15 \mathrm{ab}$ & $17.61 \pm 1.42 \mathrm{ab}$ & $19.92 \pm 6.73 \mathrm{a}$ \\
\hline Ser & $13.77 \pm 1.37 \mathrm{~b}$ & $24.84 \pm 2.03 \mathrm{a}$ & $21.55 \pm 2.68 \mathrm{a}$ & $24.59 \pm 3.74 \mathrm{a}$ & $27.29 \pm 1.56 \mathrm{a}$ & $22.70 \pm 7.25 \mathrm{a}$ \\
\hline Glu & $19.91 \pm 0.59 \mathrm{~b}$ & $38.79 \pm 12.22 \mathrm{a}$ & $36.73 \pm 3.16 \mathrm{a}$ & $46.19 \pm 1.55 \mathrm{a}$ & $50.21 \pm 5.90 \mathrm{a}$ & $43.6397 \pm 15.34 \mathrm{a}$ \\
\hline Gly & $8.13 \pm 1.14 \mathrm{c}$ & $15.02 \pm 2.09 \mathrm{ab}$ & $11.66 \pm 1.00 \mathrm{bc}$ & $16.47 \pm 0.67 \mathrm{a}$ & $15.94 \pm 1.85 \mathrm{ab}$ & $15.72 \pm 4.84 \mathrm{ab}$ \\
\hline His & $18.72 \pm 2.00 \mathrm{c}$ & $32.43 \pm 3.79 \mathrm{~b}$ & $39.67 \pm 10.17 \mathrm{ab}$ & $16.47 \pm 0.67 \mathrm{a}$ & $42.16 \pm 1.39 \mathrm{ab}$ & $35.02 \pm 8.26 \mathrm{ab}$ \\
\hline Arg & $77.57 \pm 24.24 \mathrm{c}$ & $203.93 \pm 64.31 \mathrm{a}$ & $189.35 \pm 43.07 \mathrm{ab}$ & $230.64 \pm 27.22 \mathrm{a}$ & $151.72 \pm 18.72 \mathrm{abc}$ & $119.55 \pm 34.51 \mathrm{bc}$ \\
\hline Thr & $20.96 \pm 2.97 \mathrm{~b}$ & $47.24 \pm 16.86 \mathrm{a}$ & $48.55 \pm 6.08 \mathrm{a}$ & $53.35 \pm 4.74 \mathrm{a}$ & $57.28 \pm 9.24 \mathrm{a}$ & $38.86 \pm 14.67 \mathrm{ab}$ \\
\hline Ala & $14.58 \pm 1.85 \mathrm{~b}$ & $30.73 \pm 11.62 \mathrm{a}$ & $29.64 \pm 6.04 \mathrm{a}$ & $35.01 \pm 2.85 \mathrm{a}$ & $34.95 \pm 4.16 \mathrm{a}$ & $27.85 \pm 9.62 \mathrm{a}$ \\
\hline Pro & $10.74 \pm 0.73 \mathrm{c}$ & $11.66 \pm 4.89 \mathrm{c}$ & $13.54 \pm 1.12 \mathrm{bc}$ & $16.88 \pm 0.97 \mathrm{abc}$ & $20.14 \pm 1.99 \mathrm{ab}$ & $21.52 \pm 6.73 \mathrm{a}$ \\
\hline Cys & $5.60 \pm 1.38 \mathrm{a}$ & $1.36 \pm 0.73 \mathrm{~b}$ & $0.96 \pm 0.24 \mathrm{~b}$ & $0.12 \pm 0.50 \mathrm{~b}$ & $0.20 \pm 0.41 \mathrm{~b}$ & $8.81 \pm 5.00 \mathrm{a}$ \\
\hline Tyr & $12.32 \pm 1.66 \mathrm{~b}$ & $11.05 \pm 3.22 \mathrm{~b}$ & $10.99 \pm 2.84 \mathrm{~b}$ & $13.77 \pm 1.72 \mathrm{ab}$ & $13.65 \pm 1.81 \mathrm{ab}$ & $18.24 \pm 5.37 \mathrm{a}$ \\
\hline Val & $10.46 \pm 0.78 \mathrm{c}$ & $11.21 \pm 2.94 \mathrm{bc}$ & $10.74 \pm 2.45 \mathrm{c}$ & $16.75 \pm 2.03 \mathrm{ab}$ & $16.79 \pm 1.94 \mathrm{ab}$ & $18.24 \pm 5.99 \mathrm{a}$ \\
\hline Met & $10.09 \pm 0.34 \mathrm{~b}$ & $6.46 \pm 1.74 \mathrm{c}$ & $6.65 \pm 1.51 \mathrm{c}$ & $9.00 \pm 1.25 \mathrm{bc}$ & $8.40 \pm 1.04 \mathrm{bc}$ & $13.07 \pm 2.61 \mathrm{a}$ \\
\hline Lys & $14.76 \pm 1.05 \mathrm{~b}$ & $19.93 \pm 5.16 \mathrm{ab}$ & $19.15 \pm 3.63 \mathrm{ab}$ & $28.99 \pm 2.90 \mathrm{a}$ & $29.87 \pm 4.67 \mathrm{a}$ & $29.87 \pm 11.98 \mathrm{a}$ \\
\hline Ile & $10.06 \pm 0.55 \mathrm{bc}$ & $7.61 \pm 1.94 \mathrm{bc}$ & $7.08 \pm 1.61 \mathrm{c}$ & $11.54 \pm 1.47 \mathrm{~b}$ & $11.41 \pm 1.44 \mathrm{~b}$ & $15.61 \pm 4.40 \mathrm{a}$ \\
\hline Leu & $11.80 \pm 0.81 \mathrm{~b}$ & $15.83 \pm 4.09 \mathrm{ab}$ & $16.31 \pm 3.13 \mathrm{ab}$ & $22.78 \pm 3.45 \mathrm{a}$ & $21.64 \pm 2.36 \mathrm{a}$ & $21.86 \pm 7.03 \mathrm{a}$ \\
\hline Phe & $10.73 \pm 0.59 \mathrm{~b}$ & $8.37 \pm 2.47 \mathrm{~b}$ & $8.75 \pm 1.72 \mathrm{~b}$ & $12.55 \pm 2.44 \mathrm{~b}$ & $11.83 \pm 1.48 \mathrm{~b}$ & $17.18 \pm 4.63 \mathrm{a}$ \\
\hline total & $282.51 \pm 38.62 \mathrm{~b}$ & $468.56 \pm 134.02 \mathrm{a}$ & $481.38 \pm 86.62 \mathrm{a}$ & $602.09 \pm 54.92 \mathrm{a}$ & $545.90 \pm 66.01 \mathrm{a}$ & $487.72 \pm 154.41 \mathrm{a}$ \\
\hline
\end{tabular}

Note :FAA are expressed as mean \pm S.D. of triplicates; means within the same line with common superscripts are not significantly different (P>0.05). 


\subsection{The Correlation between Small Peptides and Amino Acids}

Using the correlation analysis of SAS8.2, the correlation equation $y=1.0879 x+384.43\left(\mathrm{R}^{2}=0.86\right)$ which was obtained for the small peptide and amino acid.

\section{DISCUSSION}

The processing time of the ducks was shorter (about 21 days) and the salt content of the products was higher (about 10\%), which could be neglected the role of microorganisms in the formation of small peptides and free amino acids. In contrast muscle endogenous protease had strong ability to decompose muscle protein, among which cathepsin B, H, L, D and other decomposition was strong. In the process of processing, the muscle protein was first acted upon by cathepsin/calcein, decomposed into short peptides, and then decomposed by aminopeptidase to produce free amino acids. Capillary electrophoresis showed that a large number of peptides were produced by peptidase during the dry maturation of ham, especially in I and III dangks, some of which were associated with special tastes ${ }^{[11]}$. The peptide peptides obtained by RPHPLC showed that the increase in peak area could be noted in the accumulation of free amino acids during maturation.

FAA in the cured products in the taste characteristics has been reported. Ventanas ${ }^{[12]}$ studied the degradation of muscle protein in Iberian ham processing and found that muscle protein degraded in different degrees during processing, and the content of peptide, nonprotein nitrogen and free amino acid increased gradually. Zhang Yajun et al ${ }^{[2]}$ studied Jinhua ham in the aspartic acid, glutamic acid on the role of flavor, phenylalanine, methionine, isoleucine, valine, histidine and other effects on bitter taste, serine, Glycine, arginine, proline and other effects on the sweet. In the processing of flakes and ducks, the FAA with flavor had a specific proportion combination and high $\mathrm{NaCl}$ content, which was the key factor to produce flavor characteristics.

\section{CONCLUSION}

During the different stages of processing in nanjing dry-cured duck, the content of small peptides showed a significant increase $(\mathrm{P}<0.05)$ at the beginning stage, then decreased in the dry pickled stage and finally increased and stabilized. By using HPLC analysis of the free amino acids, in addition to arginine, threonine, cysteine little be changed, the other kind of free amino acids concentration with the processing time had different degrees of increase, which was a flavor of glutamic amino acid could be risen highest. From the total amount of change, the free amino acid from the beginning of the raw materials to dry $5 \mathrm{~d}$ could be continuously increased, and then could be slightly declined.

\section{ACKNOWLEDGMENT}

This work is supported by Fund Project: Institutional collaboration research (NSFPT1415).

\section{REFERENCES}

[1] Monica Flores,Gasey C Crimm,et al. Correlation of Sensory and Volatile Compounds of Spanish "Serrano"Dry-cured Ham as a Function of Two Processing Times. AgricFood Chem, 45,2178-2186. (1997).

[2] Zhang Yajun.The Relationship between Protein Degradation and Quality of Jinhua Hams.Zhejiang University Master Degree Thesis, Hangzhou, 2004.

[3] Silvina F., Yolanda S., Graciela V., et al. Hydrolysis of pork muscle sarcoplasmic proteins by Lactobacillus curvatus and lactobacillus sake. Appl Environ Micro. 65, 578-584 (1999).

[4] Martin L., Antequera T., Ventanas J., et al. Free amino acids and other non-volatile compounds formed during processing of Iberian ham. Meat Science. 59,363-368 (2001).

[5] Javier Moya V., Monica F. Evolution of hydrophobic polypeptides during the ageing of exudative and non-exudative pork meat . Meat Science.57, 395-401(2001)

[6] Cordoba J J,Antequera T,Carcia C., et al. Evolution of free amino acids and amines during ripening of Iberian cured ham[J] . Journal of Agriculture and Food Chemistry,1994,2(10):2296-2301.

[7] Hughes M.C.,Neill E.E.,McSweeney P.L.H. Proteolysis of bovine F-actin by cathepsin[J] . Food Chemistry , 64,525-530(1999)

[8] Hughes M.C.,Kerry J.P.,Arendt E.K.,et al. Characterization of proteolysis during the ripening of semi-dry fermented sausages. Meat Science. 62,205-216(2002).

[9] Rodriguez-Nune E. Maria-Concepcion Aristoy.peptide generation in the processing of dry-cured ham . Food chemistry.53,187190(1995).

[10] Zhao Gaiming.Studies on the Effects of Muscle Proteolytic Enzymes in the Processing of Jinhua Ham. Naning Agricultural University Doctor Degree Thesis,Nanjing,2005.

[11] Fidel Toldra. Proteolysis and Lipolysis in Flavor Development of Dry-cured Meat products[J] . Meat Science.49,101-110(1998).

[12] Antequera T., Ventanas J., et al. Lipid oxidative changes in the processing of Iberian pig ham[J] . Food Chemistry. 45,105110(1992). 